\title{
Juha Hämäläinen
}

\section{Vanhempainkasvatus \\ - haaste aikuiskasvatukselle}

Hämäläinen, Juha 1986. Vanhempainkasvatus - haaste aikuiskasvatukselle. Aikuiskasvatus 6, 1, 20-27. - Artikkelissa tarkastellaan vanhempainkasvatuksen lähtökohtia, tavoitteita ja kehittämistarpeita. Vanhempainkasvatuksen kehittäminen nähdään erityisesti aikuiskasvatuksen alaan kuuluvaksi tehtäväksi. Varsinkin vanhempainkasvatuksen erityisongelmiin paneutuvan aikuisdidaktisen tutkimuksen ajatellaan palvelevan vanhempainkasvatuksen kehittämistä kulttuurin ja yhteiskunnallisen rakentamistyön osatekijänä. Lisäksi tarvitaan vanhempainkasvatuksen integroimista yhteiskunnan tiede-, koulutus- ja hallintojärjestelmään.

\section{Vanhempainkasvatuksen käsite}

Maatalousvaltaisessa, suurperheistä rakentuneessa yhteiskunnassa perhe-elämän kannalta välttämättömät tiedot ja taidot välittyivät luontevasti sukupolvelta toiselle. Modernissa, kaupungistuneessa elämänmuodossa sosialisaatio on pirstoutunut, minkä seurauksena myös perhe- ja lastenkasvatustietouden välittyminen nuorille vanhemmille ja perhettä perustaville nuorille on häiriytynyt. Jatkuvan kasvatuksen lisäämisen tarve yhteiskunnassa koskee myös vanhempainkasvatusta.

Länsimaisen oikeuskäsityksen mukaan vanhemmilla on ensisijainen oikeus kasvattaa omia lapsiaan. Tämä periaate itse asiassa on tunnusomainen useimmille ihmisten yhteisöille ja kulttuureille ja on kirjattu myös YK:n ihmisoikeuksien julistuksen 26. artiklaan. Vanhempien kasvatusoikeus merkitsee myös sitä, että vanhemmat ovat ensisijaisesti vastuussa lastensa kehityksestä, terveydestä ja hyvinvoinnista. Mutta toisin kuin joskus halutaan uskoa, se ei merkitse, että vanhemmat "automaattisesti" osaisivat kasvattaa oikein. 
Vanhempainkasvatuksessa pyritään opettamaan vanhemmille perheen jäsenenä elämistä ja lastenkasvatusta. Se sisältää vanhemmuuteen ja lastenkasvatukseen liittyvää tietojen jakamista, taitojen harjoittamista ja asennekasvatusta. Vanhempainkasvatus tulee käsitteellisesti erottaa psykoterapiasta ja avioliittoneuvonnasta, jotka ovat henkilö- ja suhdeorien- toituneita toimintamuotoja. Vanhempainkasvatus on pikemmin tehtäväsuuntautunutta ja kognitiivisesti painottunutta. Sen sisällöllinen painopiste on vanhemmuuteen liittyvien tehtävien hoitamisessa, lastenkasvatusvalmiuksien hankkimisessa ja perheen vuorovaikutussuhteiden kehittämisessä. (Taulukko 1) (Lamb \& Lamb 1978; Fine 1980)

Taulukko 1. Vanhempainkasvatuksen käsitteen sisällön ja alan hahmottelua. (Soveltaen Lamb \& Lamb 1978, 16)

Vanhempainkasvatus on
Lasten kasvatuksen ja hoidon opettelua ja har-
joittelua
Lapsen normaaliin kehitykseen liittyvien asioi-
den opiskelua
Kommuinikaatiotaitojen opettelua
Toimintaa, joka perustuu olettamukseen, jon-
ka mukaan tietyt taidot ovat yhteydessä "pa-
rempaan vanhemmuuteen"' ja että nämä taidot
voidaan oppia

Tehtäväsuuntautunutta

Jo vanhalla ajalla kirkkoisä Hieronymus opetti vanhempia lastenkasvatuksessa. Uuden ajan alusta lähtien pyrkimys vanhempainkasvatukseen voimistui, kun Luther, Comenius, Rousseau, Pestalozzi, Fröbel ja eräät muut teoreetikot kiinnittivät kasvatusopillisissa kirjoituksissaan huomiota vanhempien edellytyksiin toimia lastensa kasvattajina. Itse vanhempainkasvatuksen käsite (Parent Education, Elternbildung, L'Education des Parents) on kuitenkin syntynyt vasta tällä vuosisadalla. (ks. Strunk 1976)

Vanhempainkasvatus voidaan nähdä "interventiona", pyrkimyksenä vaikuttaa epäsuorasti lasten persoonallisuuden kehitykseen. Tukemalla vanhempia heidän kasvatustehtävässään ja edistämällä perheen vuorovaikutussuhteiden kehittymistä vanhempainkasvatus luo suotuisaa kasvupohjaa lasten kasvulle ja kehitykselle. Useimmissa vanhempainkasvatusohjelmissa ensisijaisena tavoitteena ja toiminnan kriteerinä pidetään lapsen terveyttä ja tasapainoista kehitystä (ks. Fine 1980; Lamb \& Lamb 1978; Bronfenbrenner 1976; Dokecki \& Morony 1983).
Vanhempainkasvatus ei ole

Vanhempien psykoterapiaa

Avioliittoneuvontaa tai perheen terapiaa

Ensisijaisesti vanhempien auttamista vapautumaan omasta lapsuudestaan

Paikka, jossa vanhemmat valittavat lapsistaan tai nykyajan kakaroista

Henkilö- ja suhdesuuntautunutta

\section{Vanhempainkasvatuksen tavoitteet}

\subsection{Perhekohtaiset tavoitteet}

Vanhempainkasvatuksessa on viime kädessä kysymys koko perheen hyvinvoinnin edistämisestä ja perheenjäsenten välisten tunne- ja kommunikaatiosuhteiden kehittämisestä. Tähän tavoitteeseen pyritään välittämällä vanhemmille perhe- ja latenkasvatustietoutta. Vanhempainkasvatuksen "peruskaavan" (Bäuerle 1976) mukaan uusi tieto synnyttää vanhemmissa uutta tietoisuutta, mikä puolestaan saa aikaan muutosta vanhempien käyttäytymisessä ja perheen elämäntavassa. "'Uusi tietoisuus" tarkoittaa syventynyttä näkemystä itsestä, lapsesta tai lapsista, kasvatustehtävästä, puolisosta ja perheestä, yhteistyöstä toisten kasvattajien (opettajat, lastentarhanopettajat, kerho-ohjaajat) kanssa sekä niistä ehdoista ja olosuhteista, joissa perhe toimii ja lapset kasvavat. 
Vanhempainkasvatukselle voidaan asettaa useita perhekohtaisia tavoitteita, kuten vanhempien kasvatus- ja perhetietoisuuden syventäminen, vanhempien kasvatusasenteiden muuttaminen, vanhempien kasvattajana tunteman epävarmuuden vähentäminen ja vanhempien ja lasten välisen vuorovaikutuksen kehittäminen pedagogisesti tarkoituksenmukaiseksi. Kasvatus- ja perhetietoisuuden syveneminen merkitsee lisääntyvää arvostelukykyä ja uudenlaista asennoitumista kasvattajana ja perheen jäsenenä. Perheen vuorovaikutussuhteiden kehittäminen ilmenee muun muassa vanhempien kasvatustyön pedagogisen tason kohoamisena, mikä edelleen heijastuu lasten kehitykseen ja käyttäytymiseen. Siten vanhempainkasvatuksen tavoitteet kytkeytyvät perhe-elämän kokonaisuuteen.

Modernissa yhteiskunnassa vanhempien kasvatustehtävään sisältyy yhä enenevässä määrin kasvuvirikkeiden koordinointia ja kontrollointia: erilaisten kasvuvirikkeiden yhteensovittamista ja karsimista lapsen tasapainoisen kehityksen turvaamiseksi ja lapsen suojelemista haitallisilta vaikutteilta. Jakku-Sihvosen (1982) mukaan juuri koordinointi- ja kontrollintitehtävien menestyksellinen hoito edellyttää vanhemmilta kasvatusta koskevaa tietämystä, selkeää ja johdonmukaista kasvatusajattelua sekä kykyä arvioida ja analysoida erilaisten kasvuvirikkeiden vaikutuksia lapseen.

Pelkistetysti voidaan sanoa, että vanhempainkasvatuksen tavoitteena on vastata vanhempien tuen tarpeeseen lastenkasvatustehtävän hoitamisessa. Varsinkin sukulaisistaan kaukana asuvat nuoret vanhemmat saattavat kokea itsensä hyvin epävarmoiksi ja alemmuudentuntoisiksi kasvattajiksi. Vanhempien epävarmus, sopimattomat kasvatuskäytänteet ja kyvyttömyys kohdata lapsen tarpeita heijastuvat perheen vuorovaikutussuhteisiin ja lapsen persoonallisuuden kehitykseen. Vanhempainkasvatusta ei kuitenkaan tulisi nähdä yksinomaan ennaltaehkäisevänä erityispedagogisena toimintana, vaan pikemmin kaikkia vanhempia ja perheitä palvelevana aikuiskasvatuksen alana. Siitä voivat rikastua ja hyötyä myös ne vanhemmat, joilla ei ole erityisiä ongelmia lastenkasvatuksessa ja jotka eivät välttämättä koe itseään epävarmoiksi kasvattajana.

\subsection{Vanhempainkasvatuksen yhteiskunnallinen tehtävä}

Tarkastellessaan perheessä tapahtuvaa kasvatusta Kosmale (1976) huomauttaa, että kas- vatus - tai tarkemmin sanottuna sosialisaatioprosessi - ei ala koulussa, eikä edes esikoulussa tai lastentarhassa, vaan kasvatus alkaa lapsen ensimmisinä elinkuukausina perheessä. Lapsen varhaisessa kasvatuksessa tapahtuvat virheet ja laiminlyönnit ovat korjaamattomia: ne ovat usein syynä myöhemmin ilmeneville käyttäytymishäiriöille, integraatio-ongelmille ja erilaisille vaurioille yksilön persoonallisuudessa. Siksi yhteiskunnassa ei ole sellaista instituutiota, joka kykenisi korvaamaan perheen sen alkuperäisessä sosiaalistamistehtävässä. (Kosmale 1976, 38-39).

Monet yhteiskunnan sosiaaliset ongelmat, kuten rikollisuus, päihteiden väärinkäyttö ja mielenterveysongelmat, kytkeytyvät perheen ongelmiin. Vanhempainkasvatus voidaan nähdä $y h$ teiskunnan pyrkimyksenä puolustautua ja eliminoida näiden ongelmien syntymistä. Esimerkiksi Suomen uudessa sosiaalilainsäädännössä (Laki 1983a; Laki 1983b), jossa painotetaan lapsen huoltajan velvollisuutta turvata lapsen tasapainoinen kehitys ja hyvinvointi, korostetaan myös huoltajan oikeutta saada yhteiskunnalta tukea lastenkasvatustehtävässään. Tässä mielessä formaalinen vanhempainkasvatus voidaan ymmärtää osaksi yhteiskunnan harjoittamaa perhepolitiikkaa - samalla kun sillä on preventiivinen tehtävä yhteiskunnassa: sosiaalisten ongelmien ehkäiseminen.

\section{Perhe- ja lastenkasvatus- tietouden välittyminen vanhemmille}

\subsection{Epävirallinen sosiaalinen verkosto tietouden välittäjänä}

Epävirallinen sosiaalinen verkosto - ystävät, naapurit ja sukulaiset - vaikuttaa vanhempien rooliin lähinnä kolmella tavalla: antamalla emotionaalista ja materiaalista tukea, kontrolloimalla vanhempien kasvatustapoja ja menettelyjä ja tarjoamalla käyttökelpoisia roolimalleja ja esimerkkejä vanhempana toimimisesta. Epävirallisen sosiaalisen verkoston kautta välittyy perhe- ja lastenkasvatustietoutta vanhemmille usein hyvinkin tehokkasti. Kiinteän ja usein toistuvan vuorovaikutuksen ystäviin ja naapureihin on todettu vähentävän lapsuuden kodista saatujen mallien käyttöä vanhemman roolissa. Lisäksi sen on todettu edistävän kyvykkyyden kokemista vanhempana ja lisäävän vanhempien herkkyyttä havaita lapsen tarpeita. (Cohran \& Bassard 1979)

Sosiaalisissa suhteissa esiintyvät puutokset lisäävät nuorten äitien kohdalla yhteiskunnan 
tarjoamien palveluiden käyttöä (Strandén 1982). Yhteiskunnan viralliset tukimuodot eivät kuitenkaan välttämättä kykene korvaamaan puutosta, mikä syntyy yhteyden katkeamisesta epäviralliseen sosiaaliseen verkostoon. Pelkän kasvatustiedon ilman ystävien antamaa tukea on arveltu jopa heikentävän vanhempien itseluottamusta ja itsearvostusta kasvattajana (Cohran \& Bassard 1979). Epävirallisen sosiaalisen verkoston antamaan "vanhempainkasvatukseen" saattaa liittyä sellaisia laadullisia aspekteja, joita virallisessa vanhempainkasvatuksessa ei koskaan ole mahdollista saavuttaa.

Laajassa amerikkalaisessa (1458 tapauksen) kartoituksessa todettiin alle $36 \mathrm{kk}: \mathrm{n}$ ikäisten lasten äitien saavan epävirallisen sosiaalisen verkoston kautta tietoa erityisesti perhe-elämän ongelmista ja lastenkasvatuksesta, varsinkin lapsen elinympäristön järjestelyjä koskevista asioista. Sen sijaan lapsen kehitystä koskevissa asioissa lääkärit ja terveydenhoitajat sekä kirjallisuus olivat useimmille äideille merkittävämpi tietolähde kuin ystävät. (Sparling \& Lowman 1983)

\subsection{Puoliviralliset tiedonvälityskanavat}

Puolivirallisina vanhempainkasvatuksen muotoina voidaan pitää vanhemmuutta ja lastenkasvatusta tarkastelevaa kirjallisuutta ja aikakauslehdistöä, vanhemmille tarkoitettuja leirejä, kursseja ja seminaareja, joukkotiedotusvälineiden vanhempainkasvatusohjelmia ja videotekniikan mahdollistamaa tarjontaa vanhemille. Puolivirallisen vanhempainkasvatuksen tarjonta on viime vuosina Suomessakin voimakkaasti lisääntynyt.

Schafferin (1979) mukaan vanhempien tiedontarpeita tyydyttämään on viime aikoina kehittynyt todellinen teollisuudenhaara. Sekä vanhempainkasvatuskirjallisuus että vanhemmille tarkoitetut seminaarit perustuvat usein popularisoituun tutkimustietoon ja sen pohjalta kehiteltyihin vanhempainkasvatusmalleihin. Varsinkin Yhdysvalloissa on syntynyt tällä vuosisadalla lukuisia vanhempainkasvatuksen suuntauksia, jotka yleensä pohjautuvat johonkin persoonallisuusteoriaan tai sen sovellutukseen (ks. Fine 1980; Lamb \& Lamb 1978).

Suomessa puolivirallista vanhempainkasvatustoimintaa toteuttavia organisaatioita ovat kirkko ja seurakunnat, Mannerheimin Lastensuojeluliitto, Lastensuojelun keskusliitto ja eräät muut järjestöt sekä muutamat yksittäiset yhdistykset. Julkaisutoimintansa lisäksi nämä organisaatiot järjestävät vanhemmille leirejä ja seminaareja, joiden aiheina ovat vanhem- muus, perhe-elämä ja lastenkasvatus.

Puolivirallisen vanhempainkasvatuksen ilmeinen menestys ja elinvoimaisuus perustuu kaiketi siihen "markkinarakoon", mikä syntyy vanhempien epävarmuudesta ja tarpeesta saada tietoa lastenkasvatuksesta ja perheen vuorovaikutussuhteiden hoitamisesta. Kirjallisuus, lehdet, filmit ja seminaarit voidaan nähdä yrityksenä vastata yhteiskunnassa vallitsevaan perhe- ja lastenkasvatustietouden käyttääksemme kaupallista ilmaisua - kysyntään. Puolivirallinen vanhempainkasvatus saattaa tarjota merkittävää apua ja tukea sitä tarvitseville vanhemmille, vaikka siihen usein liittyvät kaupalliset intressit saattavatkin heikentää esitettyjen tietojen tieteellistä pätevyyttä ja johtaa liialliseen popularisointiin.

\subsection{Yhteiskunnan virallinen vanhempainkasvatus}

Yhteiskunnan virallinen vanhempainkasvatus liittyy kiinteästi yhteiskuntapolitiikan, erityisesti perhepolitiikan arvioihin ja tavoitteisiin. Suomalaisessa yhteiskunnassa virallisesta vanhempainkasvatuksesta vastaavia instituutioita ovat lähinnä terveyskeskusten neuvolat, koulut ja päiväkodit. Tosin vanhempien ohjaaminen ja neuvonta on opettajan ja lastentarhanopettajan toimenkuvassa melko uusi asia, mikä vaikeuttaa vanhempainkasvatuksen antamista kouluissa ja päiväkodeissa (ks. Taskinen \& Tirkkonen 1984).

Suomalaisen terveydenhuollon kehittämisessä yhtenä keskeisenä tavoitteena on perhekeskeisten työmuotojen kehittäminen. Pyrkimys perhekeskeisiin työmuotoihin on erityisen tyypillistä neuvolatyölle, jossa perhekeskeisyyden puuttuminen on aikaisemmin koettu suurena ongelmana. Nykyisen järjestelmän kehittämistä koko perheen terveysneuvontaan keskittyväksi perheneuvolajärjestelmäksi, jossa neuvonta laajenee koskemaan myös kasvatusta, lastenhoitoa ja koko perheen hyvinvointia, on esitetty ja suunniteltu (ks. Taulukko 2).

Taulukossa 2 esitettyjen lyhyen aikavälin tavoitteiden saavuttaminen luo edellytykset pitkän aikavälin tavoitteiden saavuttamiselle. Perhekohtainen neuvolatyökin pyrkii viime kädessä turvaamaan lapsen terveen ja tasapainoisen kehityksen. Samaan tavoitteeseen pyrkivät myös perheneuvolat (entiset kasvatusneuvolat), joiden tehtävänä on "'tukea ja edistää lasten ja perheiden myönteistä kehitystä järjestämällä ohjausta, neuvontaa ja muuta asiantuntija-apua ihmissuhteisiin, perhe-elämään ja lasten kasvatukseen liittyvissä kysy- 
Taulukko 2. Perhekohtaisen neuvolatyön tavoitteet. (Soveltaen Nupponen 19785, 527; Rimpelä 1976, 280)

\begin{tabular}{|c|c|c|}
\hline & $\begin{array}{l}\text { Lyhyen aikavälin } \\
\text { tavoitteet }\end{array}$ & $\begin{array}{l}\text { Pitkän aikavälin } \\
\text { tavoitteet }\end{array}$ \\
\hline TERVEYS & $\begin{array}{l}\text { Äidin ja lapsen terveys raskausaika- } \\
\text { na ja synnytyksessä } \\
\text { Terveyttä tukevat elintavat perhees- } \\
\text { sä }\end{array}$ & $\begin{array}{l}\text { Perheen terveystottumukset ja per- } \\
\text { heenjäsenten terveys } \\
\text { Lapsen terveyskasvatus kodissa }\end{array}$ \\
\hline HYVINVOINTI & $\begin{array}{l}\text { Perheenjäsenten psyykkinen hyvin- } \\
\text { vointi ja mielenterveys } \\
\text { Puolisoiden keskinäinen suhde hyvä } \\
\text { ja hoidettu } \\
\text { Taito käyttää yhteiskunnan tarjoa- } \\
\text { mia palveluita hyvinvoinnin edistä- } \\
\text { miseksi }\end{array}$ & $\begin{array}{l}\text { Äidin ja isän myönteinen asenne } \\
\text { vanhemmuuteen, lapseen ja perhe- } \\
\text { elämään } \\
\text { Halu täydentää lapsen hoitoa ja kas- } \\
\text { vatusta koskevaa tietoa } \\
\text { Perheen hyvinvointi }\end{array}$ \\
\hline KEHITYS & $\begin{array}{l}\text { Sopeutuminen äitiyteen, isyyteen ja } \\
\text { ja vanhemmuuteen } \\
\text { Tiedolliset ja asenteelliset valmiudet } \\
\text { tukea lapsen kehitystä }\end{array}$ & $\begin{array}{l}\text { Suotuisa perheilmasto lapsen kehi- } \\
\text { tykselle } \\
\text { Lapsen terve ja tasapainoinen kehi- } \\
\text { tys }\end{array}$ \\
\hline
\end{tabular}

myksissä sekä tutkimusta ja hoitoa lasten kasvatukseen ja perhe-elämään liittyvissä ongelmissa"' (Asetus 1983).

Lastensuojelulain (683/83) mukaan ',kunnan on sosiaali- ja terveydenhuoltoa, koulutointa sekä muita lapsille, nuorille ja lapsiperheille tarkoitettuja palveluja kehittäessään pidettävä huolta myös siitä, että näiden palvelujen avulla tuetaan huoltajia lasten kasvatuksessa ja kyetään saamaan selville, lasten, nuorten ja lapsiperheiden erityisen tuen tarve'. Edelleen lastensuojelulaki sanoo, että "'sosiaalilautakunnan ja muiden kunnan viranomaisten on seurattava ja kehitettävä epäkohtia ja ehkäistävä niiden syntymistä'. Myös uusien koululakien (Laki 1983c; Laki 1983d) mukaan koulun "on pyrittävä läheiseen yhteisymmärrykseen ja yhteistyöhön kodin kanssa tukemalla kotia sen kasvatustehtävässä'’. Näiden säädösten toteutuminen edellyttää vanhempia tukevan formaalisen neuvontajärjestelmän kehittämistä yhteiskunnassa. Lapsen opettaja on yksi luonnollinen neuvonantaja tukea tarvitseville vanhemmille.

Yhtenä uutena formaalisen vanhempainkasvatuksen muotona mainittakoon vielä avoin päiväkoti, joita Suomessa on kokeiluluonteisesti toiminut muutaman vuoden ajan yli kymmenellä paikkakunnalla. Sosiaalihallituksen (1983) määritelmän mukaan avoin päiväkoti on asuinalueen lapsiperheiden kohtaamispaik- ka ja kontaktikeskus, jonka tehtävänä on luoda kontakteja asuinalueen lapsiperheiden ja muiden asukkaiden välille, aktivoida vanhempia omaan toimintaan, antaa vanhemmille kasvatusneuvontaa ja välittää tietoa kunnan sosiaalipalveluista. Avoimen päiväkodin toiminnassa yhdistyvät virallinen, puolivirallinen ja epävirallinen vanhempainkasvatus: kasvatusneuvontaa toteutetaan kahdenkeskisissä ja ryhmäkeskusteluissa, minkä lisäksi toimintaan osallistuvat vanhemmat ovat toimintatilanteissa vuorovaikutuksessa keskenään saaden toisiltaan virikkeitä omaan kasvatustyöhönsä.

\section{Vanhempainkasvatuksen kehittäminen}

\subsection{Kehittämistarpeet}

Vanhempainkasvatus ei ole valmis teoreettinen rakennelma tiettyine vastaavuuksineen yhteiskunnan kasvatusjärjestelmässä. Pikemmin vanhempainkasvatukselle on tunnusomaista hajanaisuus, satunnaisuus ja teorian löyhyys. Nämä puutteet ovat samalla haaste vanhempainkasvatuksen kehittämiselle. Kehittämistyön pontimena on viimekädessä modernin perheen "rakenteellinen kasvatuspuutos", (Kosmale 1976), minkä seurauksena sosialisaatio ja lasten persoonallisuuden kehitys häiriin- 
tyvät.

Vanhempainkasvatuksen kehittämisessä olisi otettava huomioon ainakin seuraavat kehittämistarpeet:

1. Vanhempainkasvatus tarvitsee selkeän kasvatusfilosofisen perustan, mikä edellyttää sen lähtökohtana olevien arvojen selkiyttämistä. Ilman aksiologista viitekehystä vanhempainkasvatus ja sen kehittäminen ajautuvat helposti tekniseen näpertelyyn ja päämäärättömään kokeiluun.

2. Vanhempainkasvatus tarvitsee aikuisdidaktiikkaan pohjautuvan opetusopin, jossa vanhempainkasvatuksen erityispiirteet otetaan huomioon. Keskeisinä opetusmenetelmällisinä periaatteina vanhempainkasvatuksen didaktiikassa mainittakoon ongelmakeskeisyys, käytännöllisyys ja oppimisprosessin yhdistäminen vanhempien omaan elämäntilanteeseen. Näiden periaatteiden toteutuminen merkitsee avoimen opetussuunnitelman käyttöä ja vanhempien osallistumista opetuksen suunnitteluun. (ks. Strunk 1976)

3. Formaalinen vanhempainkasvatusjärjestelmä tarvitsee pätevän, hyvin koulutetun opetus- ja hallintohenkilöstön kyetäkseen välittämään vanhemmille perhe- ja lastenkasvatustietoutta tehokkaasti ja relevantilla tavalla. Tämän toteutumiseksi tarvitaan luonnollisesti myös päteviä kouluttajia ja korkeatasoista koulutusmateriaalia. Vanhempien neuvonnasta ja ohjauksesta vastaavat työntekijät tarvitsevat tiedollisten valmiuksien lisäki myös opetustaidollisia valmiuksia vanhempien kohtaamiseen, mikä on otettava huomioon myös heidän koulutuksessaan.

Vanhempainkasvatuksen kehittäminen tulisi kyetä niveltämään muuhun kasvatusjärjestelmän kehittämistyöhön. Tässä niveltämisessä on periaatteessa useita erilaisia ratkaisuvaihtoehtoja.

Vanhempainkasvatuksen sisältöjä koskevan suunnittelun lähtökohdaksi on ehdotettu "sellaisen kasvatusta koskevan tietämyksen opettamista vanhemmille, josta he hyötyisivät halutessaan kehittää itseään kasvattajina, ei vain omaksumalla tietoja, jotka ovat välttämättömiä kasvattajille, vaan myös pyrkiessään lisäämään omaa itsetiedostustaan" (Jakku-Sihvonen 1982, 217). Tällaisen vanhempainkasvatuksen tulisi rakentua jäsentyneen ja teoreettisesti pätevän tiedon varaan, mikä edellyttää määrätietoista didaktista kokeilu- ja kehittämistyötä vanhempainkasvatuksen erityisongelmien parissa. Vanhempainkasvatuksen didak- tinen kehittäminen luonnollisesti edeltää sen laajamittaista organisointia yhteiskunnassa. (Jakku-Sihvonen 1982)

Strunk (1976) painottaa vanhempainkasvatuksen kytkemistä yhdyskuntatyöhön, mikä merkitsee yhteistyötä sosiaalityöntekijöiden, kunnan eri hallintokuntien, järjestöjen ja vapaaehtoistyöntekijöiden kanssa. Vanhempainkasvatuksen kehittämisessä tarvitaan eri tahojen yhteistyötä. Kuitenkin on Bäuerlen (1976) tavoin huomautettava, että vanhempainkasvatus ei kykene vähentämään modernin pienperheen vieraantumista rakenteellisesti epävakaassa nyky-yhteiskunnassa eikä se voi ratkaista ahdistavaa asuntotilannetta, epäinhimillistä rakennuskulttuuria, tarvittavien sosiaalisten palvelujen puuttumista eikä mitään muitakaan yhteiskuntajärjestelmän synnyttämiä elinolosuhteita, jotka merkittävästi vaikuttavat perheiden elämään ja vanhempien kasvatustoimintaan. Vanhempainkasvatus lähinnä auttaa isiä ja äitejä toimimaan kasvattajan vastuullisessa tehtävässä niissä olosuhteissa, joissa he kulloinkin elävät.

Suomen aikuiskasvatusjärjestelmän uudistamissuunnitelmissa ei olla juuri lainkaan kiinnitetty huomiota aikuisille suunnatun perhekasvatuksen tarpeeseen. Esimerkiksi valtioneuvoston vuonna 1978 tekemässä aikuiskasvatuksen suunnittelu- ja kehittämisperiaatteita koskevassa päätöksessä puhutaan kansalaisten oikeudesta ja mahdollisuudesta hankkia, täydentää ja uudistaa työ-, yhteiskunta- ja kulttuurielämässä tarvittavia tietoja ja taitoja, mutta ei mainita tietoja ja taitoja, joita ihmiset tarvitsevat perhe-elämässä ja lastenkasvatuksessa. Yhtenä vanhempainkasvatuksen kehittämisen perusteita koskevana kysymyksenä onkin se, onko ylipäätään mielekästä integroida vanhempainkasvatusta viralliseen aikuiskasvatusjärjestelmään. Nimenomaan tämän järjestelmän ulkopuolella on lukuisia kanavia ja tietolähteitä, jotka välittävät perhe- ja lastenkasvatustietoutta aikuisille.

\subsection{Tutkimus ja koulutus vanhempainkasvatuksen kehittämisessä}

Tutkimus ja koulutus ovat avainkäsitteitä kaikessa modernissa kehittämistoiminnassa, myös vanhempainkasvatuksen kehittämisessä. Tutkimus ja koulutus palvelevat pätevän neuvonta- ja opetushenkilökunnan tarvetta; ne luovat edellytykset käytäntöä tukevan vanhempainkasvatuksen teorian kehittämiselle; ne tukevat vanhempainkasvatukseen liittyviä hallinnollisia ratkaisuja. 

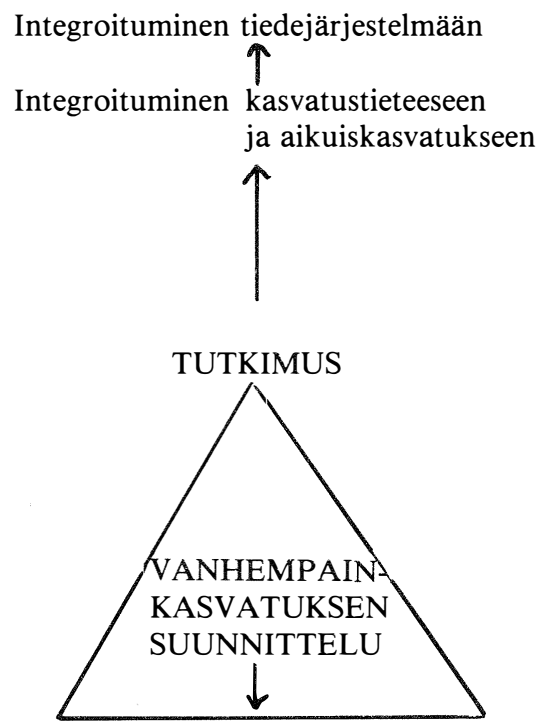

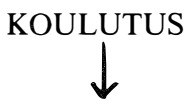

(Horisontaalinen ja vertikaalinen) integroituminen koulutusjärjestelmään (korkea-aste/keskiaste/ aikuiskasvatus)

Kuvio 1. Tutkimus, koulutus ja hallinto vanhempainkasvatuksen kehittämisessä.

Kuviossa 1 on esitetty konstruktio siitä, millä tavoin tutkimus, koulutus ja hallinto kytkeytyvät vanhempainkasvatuksen kehittämiseen yhteiskunnallisena instituutiona.

Tutkimus, koulutus ja hallinto luovat edellytyksiä vanhempainkasvatuksen muodolliselle ja sisällölliselle kehittämiselle yhtenä yhteiskunnan instituutiona. Samalla ne ovat keskeisiä kehittämistyön kohteita. Vanhempainkasvatuksen integroiminen yhteiskunnan tiede-, koulutus- ja hallintojärjestelmään vahvistaa sen asemaa kulttuurin ja yhteiskunnallisen rakentamistyön osatekijänä. Sellaisena se voi merkittävällä tavalla palvella perheitä, vanhempia ja lapsia sekä lopulta koko yhteiskuntaa.
Vanhemmuus ja perhe ovat monen eri tieteenalan tutkimuskohteena. Psykologinen, kehityspsykologinen, sosiologinen, antropologinen, lääketieteellinen, hoitotieteellinen, väestötieteellinen, yhteiskuntapoliittinen ja filosofinen perhetutkimus palvelevat kukin omalla sarallaan ja omalla tavallaan vanhempainkasvatuksen teorian ja käytännön kehittämistä. Itse vanhempainkasvatuksen teorian muodostaminen ja vanhempainkasvatuskäytännön ja sen edellytysten, koulutuksen ja hallinnon, kehittäminen ovat kuitenkin lähinnä kasvatustieteen ja siinä aikuiskasvatuksen alaan kuuluva tehtävä.

Vanhempainkasvatusta voidaan tarkastella yhteiskunnallisena, poliittisena ja juridisena ongelmana, kuten kaikkea yhteiskunnassa tapahtuvaa kasvatusta. Tällöin yhteiskuntapoliittinen ja sosiologinen tutkimus voivat palvella kehittämistyötä. Vanhempainkasvatuksen ensisijainen kehittämistarve lienee kuitenkin didaktiikan alueella, oeptusmenetelmien kehittämisessä (mm. Bäuerle 1976; Strunk 1976). Se merkitsee erityistä haastetta aikuisdidaktiselle tutkimukselle.

Formaalista vanhempainkasvatusta toteuttavat työntekijäryhmät tarvitsevat vankan peruskoulutuksen lisäksi myös jatkuvaa työnohjausta ja säännöllistä täydennyskoulutusta vanhempien kanssa tehtävään työhön. Tiedollisten valmiuksien ohella opetustaidollisilla valmiuksilla on keskeinen asema tässä koulutuksessa. Vanhempien kohtaamisessa ja opettamisessa tarvittavat taidot saattavat poiketa suuresti niistä opetuskäytänteistä, joita esimerkiksi lastentarhanopettajat, luokanopettajat tai terveydenhoitajat omaksuvat ammatillisen peruskoulutuksensa aikana lasten parissa tehtävää kasvatustyötä varten. Niinpä päiväkotien antamaa lastenkasvatusneuvontaa koskevassa tutkimuksessa (Taskinen \& Tirkknen 1984) todettiin sen onnistumisen keskeisiksi edellytyksiksi lisäkoulutus, lisähenkilöstö, uudet työaikajärjestelyt ja konsultaatio. Yleisesti ottaen vanhempien kokemukset ja arviot päiväkodin lastenkasvatusneuvonnasta olivat myönteisiä.

Vanhempainkasvatus on aikuiskasvatusta. Sen didaktinen kehittäminen nojaa moderniin aikuisdidaktiikkaan. Vanhempainkasvatuksen erityispiirteet huomioon ottava aikuisdidaktinen tutkimus on edellytys sille, että vanhempainkasvatuksesta huolehtivien työntekijäryhmien koulutuksessa voidaan relevantisti kehittää vanhempien kohtaamisessa tarvittavia opetustaidollisia valmiuksia. 


\section{Lähteet}

Asetus 1983. Sosiaalihuoltoasetus. A 607/83.

Bronfenbrenner, U. 1976. Is early intervention effective? Facts and principles of early intervention: a summary. Teoksessa A.M. Clarke \& A.D. Clarke (Eds.) Early experience: myth and evidence. London: Open Books.

Bäuerle, W. 1976. Die Aufgabe der Elternbildungsarbeit. Teoksessa L. Kerstiens (Hrsg.) Elternbildung, 87-99. Heilbrunn: Verlag Julius Klinkhardt.

Cohran, M. \& Bassard, J. 1979. Child development and personal social networks. Child Development 48, 601-616.

Dokecki, P.R. \& Moroney, R.M. 1983. To strenghten all families: a human development and community value framework, 40-64. Teoksessa R. Haskins \& D. Adams (Eds.) Parent education and public policy. New Jersey: Ablex Publishing Corporation.

Fine, M.J. 1980. The parent education movement: an introduction. Teoksessa M.J. Fine (Ed.) Handbook on parent education. 3-26. New York: Academic Press.

Jakku-Sihvonen, R. 1982. Lastenkasvatustehtävä vanhempien opiskeluhalukkuuden pontimena. Helsingin yliopiston kasvatustieteen laitoksen tutkimuksia 99.

Kosmale, A. 1976. Familie und Erziehung. Teoksessa L. Kerstiens (Hrsg.) Elternbildung, 38-42. Heilbrunn: Verlag Julius Klinkhardt.

Laki 1983a. Laki lapsen huollosta ja tapaamisoikeu- desta. L 361/83.

Laki 1983b. Lastensuojelulaki. L 683/83.

Laki 1983c. Lukiolaki. L 477/83.

Laki 1983d. Peruskoululaki. L 476/83.

Lamb, J. \& Lamb, W. 1978. Parent education and elementary counseling. New York: Human Sciences Press.

Nupponen, R. 1975. Perhe neuvolatyön kohteena raskauden aikana. Sosiaalilääketieteellinen Aikakauslehti, 12, 521-527.

Rimpelä, U. 1976. Äitiyshuollon tavoitteet ja tehtävät. Suomen lääkärilehti, 31, 279-284.

Schaffer, R. 1979. Äitiys. Jyväskylä: Gummerus.

Sosiaalihallitus 1983. Teematiedote 4/83.

Sparling, J. \& Lowman, P. 1983. Parent information needs as revealed through interests, problems, attitudes and preferences. Teoksessa R. Haskins \& D. Adams (Eds.) Parent education and public policy, 304-323. New Jersey: Ablex Publishing Corporation.

Strandén, P. 1982. Nuori lapsiperhe. Tutkimus nuorten perheiden elämäntilanteesta ja toimintaedellytyksistä. Mannerheimin Lastensuojeluliiton lapsiraportti A 38. Helsinki.

Strunk, G. 1976. Erziehung in einer Gesellschaft des Ubergangs / Elternbildung im Rahmen eines situationsorientierten didaktischen Ansatzes der Erwacsenenbildung. Teoksessa L. Kerstiens (Hrsg.) Elternbildung, 7-23 / 100-122. Heilbrunn: Verlag Julius Klinkhardt.

Taskinen, S. \& Tirkkonen, A. 1984. Perhekasvatuksen kehittäminen päiväkotien ja kasvatusneuvoloiden yhteistyönä. Sosiaalihallitus julkaisuja 8/1984. Helsinki: Valtion painatuskeskus. 